\title{
Retraction Note to: Role of $p 16$ gene promoter methylation in gastric carcinogenesis: a meta-analysis
}

\author{
He-Ling Wang ${ }^{1} \cdot$ Ping-Yi Zhou ${ }^{1} \cdot$ Peng Liu $^{1} \cdot$ Yu Zhang ${ }^{1}$
}

Published online: 18 August 2015

(C) Springer Science+Business Media Dordrecht 2015

Retraction Note to: Mol Biol Rep (2014)

41:4481-4492

DOI 10.1007/s11033-014-3319-y

The Publisher and Editor retract this article in accordance with the recommendations of the Committee on Publica tion Ethics (COPE). After a thorough investigation we have strong reason to believe that the peer review process was compromised.

The online version of the original article can be found under doi:10.1007/s11033-014-3319-y.

He-Ling Wang

wangheling1127@126.com

1 Department of General Surgery, The Shengjing Hospital of China Medical University, Huaxiang Road, Tiexi District, Shenyang 110022, People's Republic of China 